\title{
УДК 343.9
}

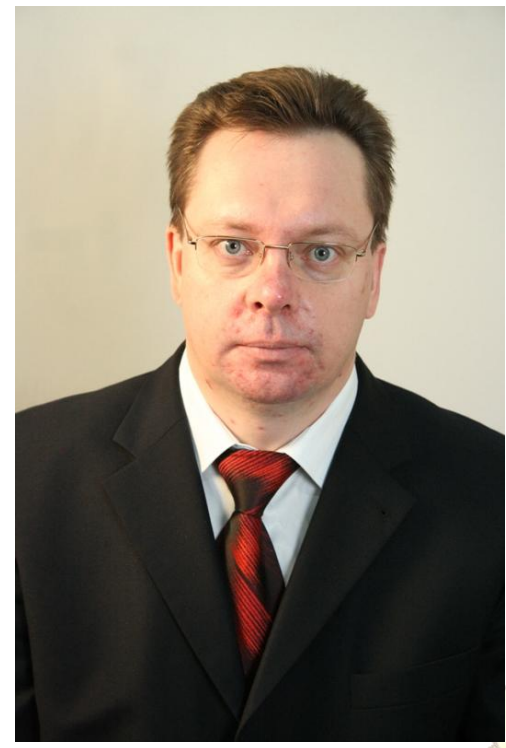

\section{ПРОФЕСІЙНА ЗЛОЧИННІСТЬ ЯК ПРОЯВ ЗЛОЧИННОГО КОРПОРАТИВІЗМУ}

\author{
В. В. ПИВОВАРОВ, \\ канд. юрид. наук, \\ доцент кафедри кримінології \\ та кримінально-виконавчого права, \\ Національний юридичний університет \\ імені Ярослава Мудрого, \\ м. Харків
}

Розглянуто явище професійної злочинності як прояв корпоративної злочинності. злочинність.

Ключові слова: корпоративна злочинність, професійна злочинність, організована

Проблемами і завданнями дослідження професійної злочинності в різний час та в різних аспектах займались такі зарубіжні та вітчизняні вчені, як Енріко Феррі [1], Габріель де Тард [2], О. І. Гуров [3], О. В. Шеслер [4], А. Ф. Зелінський [5], I. М. Даньшин [6], Г. Ф. Хохряков [7] та інші вчені - кримінологи, криміналісти, соціологи, психологи, психіатри тощо. У працях науковців проблема професійної злочинності, іï природи, змістовної сутності розглядається 3 різноманітних точок зору. Так, пропонується вважати їі окремим видом (різновидом) злочинів або ж частиною рецидивної чи організованої злочинності, або навіть різновидом злочинності політичних еліт. Відтак явщще професійної злочинності потребує уваги кримінологів і ретельного їі дослідження.

В історичній ретроспективі у злочинному світі багатьох країн здавна виокремлювались особи, які систематично вчиняли переважно корисливі злочини (крадіжки, шахрайство та ін.), досягаючи певної злочинної майстерності. При цьому вони виявляли впертість і небажання відмовлятися від такої поведінки, бо вона була для них джерелом засобів існування. Спираючись на свій багаторічний кримінальний досвід, вони розраховували на безкарність. Таких людей почали 
називати стійкими, професійними злочинцями.

Питання опису професійної злочинної поведінки таких осіб у кримінології виявилось досить проблемним. Причому поняття професійний злочинець, професійна злочинність нерідко трактувалися довільно. Тим часом проблема стійкої, тривалої, майстерної злочинної поведінки має давнє історичне коріння.

У науковій літературі зазначається, що тип професійного злочинця був виділений у класифікації правопорушників, прийнятій на Гейдельбергському з’їзді Міжнародного союзу криміналістів у 1897 р. Первісне поняття «професійний злочинець» криміналісти пов'язували 3 ознакою завзятості, небажання злочинця відмовитися від здійснення злочинів. Однак у практиці боротьби зі злочинністю, у наукових працях криміналістів, кримінологів, соціологів тип професійного злочинця з'явився значно раніше. Відомий французький вчений Г. Тард у кримінологічній праці «Порівняльна злочинність» розглядає корпорації злочинців, починаючи опис 3 аналізу діяльності італійської «камори». Злочинці-каморісти дотримувались суворих корпоративних правил. Так, перед набуттям членства вони проходили суворе випробування, а при вступі до членів давали клятву, яку дослідники вважають професійною. Організація «камора» мала ієрархічну систему управління, чітко визначений порядок вирішення спірних питань $\mathrm{i}$ жорстоку систему покарань за порушення правил злочинної поведінки. Умовно називаючи спосіб життя «камористів» «великим злочинним мистецтвом», Можна провести паралель між цим товариством злочинців і промисловою корпорацією та вказати на такі специфічні риси членів цієї спільноти, як татуювання і порізи шкіри, професійна мова чи стиль письма. Відомий італійський учений, один із засновників кримінальної соціології Е. Феррі у своїй праці «Злочинні типи в мистецтві та літературі» виділяє тип «природженого злочинця», до якого в першу чергу відносить спритних злодіїв і шахраїв та зазначає, що такий тип злочинця не обов'язково є жорстоким. Саме «природжені» злодії і шахраї, на думку Е. Феррі, будучи особистостями, обдарованими розумом вище 
середнього для злочинця рівня, однак аморальними та антисуспільними, складають прошарок «морально божевільних» злочинців, для яких вчинення злочинів є способом життя [1, с. 17-22]. Отже, ще у працях засновників науки кримінології розглядаються питання професійної злочинної діяльності в контексті виділення злочинного типу, якому властиве систематичне вчинення крадіжок, шахрайств та інших злочинів проти власності, досягнення певної спеціалізації і майстерності, невизнання суспільно корисної праці, рецидивізм, схильність до татуювань, власного жаргону тощо.

Цілком очевидно, що термін «професійна злочинність» є умовним і доволі невизначеним. Його застосування можна пояснити тим, що стійка злочинна поведінка, насамперед,зовні схожа, нагадує будь-яку іншу професійну діяльність. Розглядати професійну злочинність можна тільки скрізь призму систематичної спеціалізованої діяльності злочинця, яка зовні нагадує діяльність професійну. Власне кажучи, «професійних» по природі злочинів взагалі не існує. Наприклад, навмисне вбивство може бути вчиненим однією особою одноразово на грунті побутової сварки, а для іншої особи вбивства на/замовлення можуть стати основним джерелом існування. Врешті решт, можемо уявити особу, яка майстерно ухиляється від сплати аліментів на утримання дітей, змінює місця роботи, підробляє особистісні ідентифікаційні документи, однак навряд чи комусь спаде на думку назвати ухилення від сплати аліментів «професійним» злочином.

На початку XX ст. в Росії, як і інших країнах Свропи, вживались спеціальні заходи по боротьбі із професійною злочинністю, створювались особливі поліцейські підрозділи, картотеки та реєстраційні криміналістичні бюро. Однак вчені й правоохоронці одностайно вважали, що питома вага професійних злочинців відносно загальної чисельності злочинного «корпусу» вкрай мала, спеціальний рецидив також є незначним (наприклад, не більше 50 \% серед крадіїв). Стосовно кримінальних спеціалізацій, то вони виявилися досить розгалуженими в злочинному світі Росії. Наприкінці XIX ст. на каторзі утвердилися відповідні неформальні групи (масті). Засуджені поділялись на іванів, храпів, гравців, шпанку, сухарників, асмадєєв. На волі діяли громили 
(грабіжники), ведмежатники (зломщики сейфів), йоржі (магазинні злодії), фармазонщики (шахраї) i т.д. Лише серед злодіїв, наприклад, було 25 спеціальностей і відповідно фахівців. Згодом кримінальний світ, зберігаючи в цілому кримінальну основу дореволюційної Росії, доповнився іншими злочинними промислами. В середині XX ст. 3'являється впливове неформальне групування, яка формувалась із рецидивістів і отримало назву «вори в законі».

У радянський час професійна злочинність досліджувалась переважно в контексті рецидивізму, оскільки вважалося, що соціальних передумов для неї нема. Нечисленні дослідження того часу торкались переважно окремих видів злочинів. Точки зору криміналістів були різні, але сходилися на тому, що цей вид злочинності охоплює корисливі злочини, а злочинець-професіонал - це той, хто кілька разів вчиняв злочин того ж виду. Відзначалося також, що професіоналом міг бути й не рецидивіст.

У сучасній кримінології визначення професійної злочинності сформувалось через поняття кримінального професіоналізму. Як слушно зазначає О. І. Гуров, при з'ясуванні поняття кримінального професіоналізму слід виокремити основні три ознаки професії як такої: різновид занять, певна підготовка і отримання матеріального доходу. Додатковою ознакою $\epsilon$ соціальний зміст професії, підтримання престижу і значущості професії, створення професійної лексики і етики - тобто зв'язок індивіда із соціальнопрофесійним середовищем [3, с. 10, 19-28]. Встановивши такі компоненти професії й констатуючи зовнішній їх прояв у протиправній діяльності, слід визначити кримінальний професіоналізм як різновид злочинної діяльності, який виступає для злочинця джерелом існування, потребує відповідних знань і навичок для досягнення злочинної мети та зумовлює необхідне спілкування особи із кримінальним середовищем. Виділяються чотири ознаки кримінального професіоналізму: а) усталений різновид злочинного зайняття (спеціалізація); б) відповідні знання та навички (кваліфікація); в) вчинення злочинів для здобуття коштів на існування (злочинний промисел); г) зв'язок із кримінальним середовищем, здійснюваний через кримінальну субкультуру. 
Слід наголосити, що дійсно професійна злочинна діяльність має постійний і стійкий характер. Професійні злочинці упродовж тривалого часу багаторазово вчиняють злочини, що спочатку формує в них певну звичку, яка переростає потім у норму поведінки. Тому слід погодитись із думою тих вчених, які розглядали кримінальний професіоналізм як різновид свідомо продуманого i в усіх деталях заздалегідь підготовленого соціального паразитизму.

Як уже зазначалось, професійним злочинцям притаманна відповідна спеціалізація. Ця ознака виявляється в тому, що у кожного з них є чітка настанова на певний вид злочинних занять, вчинення тотожних або однорідних злочинів. Традиційними проявами професійної злочинності є кишенькові крадіжки, крадіжки автомашин, крадіжки із сейфів або приміщень із електронною системою охорони, шахрайство, розкрадання антикваріату, наймані вбивства й ряд інших злочинних діянь. У свою чергу, професійні злодії, шахраї та інші категорії злочинців-професіоналів різняться на основі їх більш вузької спеціалізації. Серед шахраїв, наприклад, виділяються карткові шахраї (шулери), «наперсточники», тобто гравці в «наперсток», «кукольники», що здійснюють підміну речей або грошей спеціально виготовленою їх імітацією - «лялькою», та ін.

Як правило, професійні злочинці вчиняють свій перший злочин у неповнолітньому віці. Удосконалення злочинної спеціалізації суб'єкта, 3 одночасним проходженням певного життєвого шляху, пов'язаного 3 досягненням популярності й авторитету в кримінальному середовищі, слід визначити як кримінальну кар'єру. Кожен злочинець-професіонал в основному знає таких же, як і він, осіб. Спритний злочинець пишається своєю професією й має своєрідне кримінальне мислення. Причому воно майже не залежить від загальноосвітнього рівня. Численні приклади підтверджують, що чимало злочинців, що практично вміють тільки читати, майстерно виконували підготовку, здійснення й приховування злочинів, що вимагають кмітливості й спритності. Привертає увагу те, традиція професійних злочинців «працювати» 
поодинці залишається в минулому. Характерною тенденцією останніх років $є$ розподіл злочинних «ролей», створення «конвейерних» схем злочинів, усе більш часте використання ними як співучасників осіб, котрі мають інші, некримінальні знання та навички. Серед професійних злочинців усе частіше зустрічаються особи, які спочатку одержали спеціальні військові, юридичні, спортивні й деякі інші професії та використовують ці знання не тільки при особистому вчиненні злочинів, але й виступають у ролі консультантів, привносять у спеціальні методи й способи здійснення злочинів певну новизну.

Заняття професійною злочинною діяльністю передбачає наявність у ній суб’єктів відповідної кримінальної кваліфікації, тобто необхідних знань, навичок i умінь, що забезпечують підготовку, вчинення i приховування злочинів. За їх допомогою забезпечується впевнене досягнення мети при найменшому ризику бути викритим. Кримінальна кваліфікація відпрацьовується на власному досвіді, а також у процесі постійного спілкування 3 професіоналами, які мають великий злочинний стаж. Зрештою названі навики і знання доводяться до автоматизму.

Якщо раніше більшість злочинних професій здобувалась кустарним шляхом, то згодом окремим з них стали навчати у спеціальних центрах, свого роду школах. Так, засоби масової інформації повідомляють про існування у країнах ближнього зарубіжжя так званих «кілерських центрів», де навчаються й удосконалюють кримінальні навички професіонали-убивці. Сьогодні кримінальна професійна підготовка здобуває систему підвищення злочинної кваліфікації, у якій бувають задіяні й наукові знання та розробки. Не останню роль у формуванні професійного злочинця відіграють злочинні угруповання засуджених у місцях позбавлення волі.

Особливе значення для вдосконалення злочинної кваліфікації має спілкування та взаємодія, під час яких й відбувається передача злочинного досвіду. У необхідних випадках організуються практичні заняття, наприклад, із виготовлення відмичок, вогнепальної, холодної зброї, покази безшумного проникнення на той або інший об'єкт, фізична підготовка, навчання 
рукопашному бою, володінню холодною зброєю, методам карткового й іншого шулерства й т.п.

Показово, що в останні 20 років співробітники місць позбавлення волі періодично виявляють у промислових зонах виправних установ різні тренувальні пристрої, як правило, саморобний спортивний реманент, обладнання для рукопашного бою, юридичну літературу з тактики й методики розкриття злочинів.

Далеко не завжди професійні злочинці демонстративно відмовляються від суспільно корисної праці. Перебуваючи на волі, вони все частіше обирають роботу, що не пов'язана із злочинними навичками i таким чином маскують свою справжню кваліфікацію та причетність до злочинного світу. Одержуваний при цьому заробіток не має значення, на перше місце виходять мінімальні трудові затрати, вільний графік роботи, неповна зайнятість тощо.

Як свідчить практика, противоправний прибуток професійних злочинців у наші дні є значним. Вони своїм злочинним промислом не лише забезпечують своє повсякденне «привабливе» існування, але й накопичують значний капітал. У злочинних кланах професійних злочинців протягом останніх років одержала розвиток добре фінансована злочинними доходами функція своєрідної внутрішньої безпеки, шо полягає не тільки у фізичному, але й в юридичному захисті своїх членів і осіб, що перебувають під заступництвом клану. Для чого ватажки та активні учасники формувань вживають належних заходів до налагодження корумпованих зв'язків серед державних чиновників, найму досвідчених адвокатів, установленню ділових відносин 3 лікарями, журналістами, письменниками, кінорежисерами, популярними артистами кіно, естради, театру, комерсантами, банкірами й іншими «потрібними» людьми. Причому це робиться як на матеріальній, так і на безоплатній основі, коли та або інша особа береться під фізичний захист. Злочинці-професіонали, входячи в кримінальні формування або перебуваючи під їх заступництвом, не тільки навчають злочинців-новачків протиправному ремеслу, але й приносять ватажкам злочинних структур стійкий матеріальний дохід. Сучасний «вор у 
законі», будучи лідером злочинного миру, має оточення, що складається із близьких йому людей, спільників, які у свою чергу залучають злочинціввиконавців й інших потрібних фахівців. Сьогодні авторитетний злодій у законі - це не татуйований «зек» 3 почорнілими зубами, він чисто виголений, одягнений за останньою модою, в його обслузі не тільки «шістки», але й охоронці. У повсякденному побуті лідера - кілька приватизованих квартир, дачі, автомашини престижних марок.

Для злочинців-професіоналів характерним $є$ прагнення підтримувати зв'язки 3 антисоціальним середовищем, близьким до їхньої орієнтації. Найбільш тривкі контакти вони встановлюють здебільшого зі злочинцями однієї і тієї ж спеціалізації. Систематичне ведення антисоціального способу життя викликає у них природну психологічну потребу в повсякденному спілкуванні зі своїми кримінальними однодумцями.

У середовищі професіональних злочинців існує специфічна субкультура: притаманні тільки їм традиції, звичаї, різні неформальні норми поведінки, що не відповідають загальноприйнятим в суспільстві нормам. Кримінальна субкультура відіграє суттєву роль у встановленні і підтриманні професійності. Для створення і підтримання кримінальної субкультури в середовищі професійних злочинців присутні всі необхідні передумови. Першою 3 них виступає виділення i протиставлення гурту злочинних професіоналів iз загальної структури суспільства. Іншими чинниками виступають цілі злочинного угрупування (отримання доходу), та збільшення ефективності діяльності. Такі елементи кримінальної субкультури, як норми i стиль повсякденної поведінки, татуювання, жести, мова (жаргон), сприяють результативному виконанню функцій. Наприклад, кишеньковий злодій бачить, що в міському транспорті чи на ринку «працює» його колега. Він може не знати його особисто, однак впізнає за жестами і поведінкою. Якщо собрат «засипається», то він зобов’язаний прийти на допомогу - відволікти жертву, наприклад.

Серед злочинних професіоналів поширений свій жаргон. Причому він 
досить багатий і значно відрізняється від жаргону загальнокримінального. В літературі зазначається, що у кишенькових злодіїв існує близько 400 слів, які відбивають їх діяльність; у картярів - близько 200, у розповсюджувачів наркотиків - близько 100. Відомо, що у звичайному житті для побутового спілкування достатньо 300 слів. Злочинці мають прізвиська, що призначені для приховування імен і прізвищ 3 метою забезпечення конспірації. Вони залишаються за злочинцями навіть і тоді, коли особи змінили своє прізвище і перейшли на нелегальне становище.

Стосовно татуювань, то на теперішній час вони вже втрачають стигматичну і комунікативну функцію. Скоріше, зараз це елемент «тюремної екзотики», своєрідний «літопис славетного життя». В принципі, татуювання професійному злочинцю тільки заважають: вони привертають увагу та можуть відлякати потенційну жертву. Саме тому кишеньковий злодій, наприклад, не може епатажно одягатись чи надто сильно пахнути парфюмом - це приверне небажану увагу. Звісно, в минулі роки татуювання допомагали визначити злочинну спеціалізацію, місця відбування покарань, статус у злочинному світі. На сьогодні традиції татуювання майже втрачені. Проникнення окремих елементів кримінальної субкультури до молодіжної субкультури призводить до того, що представники несудимої молоді часто наносять «модні» кримінальні татуювання, при цьому пояснити іх значення не можуть. Цікаво, що й серед сучасного покоління злочинців у віці до 40 років мало хто може впевнено прочитати символіку кримінальних татуювань.

Злочинні клани мають спільні грошові фонди («общаки»). Впровадження ринкових відносин у соціально-економічне життя країни змінило характер злочинної діяльності злодійських кланів. Причому не останню роль у цьому зіграла зміна характеру формування й використання «общакових» коштів. Якщо раніше «общак» переважно призначався для надання допомоги заарештованим і засудженим та їх родинам, у рідких випадках для організації й здійснення злочинів, а також в окремих випадках для підкупу чиновників, то 3 початку 90-х рp. XX ст. останній напрямок його використання здобуває більш 
широкий спектр. Частина «общакових» коштів вкладається як у нелегальний, так і в легальний бізнес. Причому, як не однократно відзначалося, на початку 90-х років у більшості злодійських формувань легалізація «общакових» коштів як сукупної частини злочинних доходів виділилася в окремий напрямок кримінально-комерційну діяльність. Одна з основних завдань цього напрямку забезпечення розширеного відтворення злочинної діяльності при нарощуванні коштів, матеріальних ресурсів, у тому числі спеціального призначення, для рішення певних питань силовими методами. Формується «общак» із внесків (на жаргоні - долянка, лаве, лавэшкі) від традиційного злочинного промислу наприклад, частини крадених грошей і коштовних речей, частки матеріальних коштів від поставки наркотиків, зброї тощо. Крім того, в «общак» входять також доходи від казино й ігорних притонів ( до 30-45 \%); данина у вигляді грошей, продукції, коштовностей 3 фінансово-комерційних, банківських структур, а також господарюючих суб'єктів (до 10 \% від одержуваних доходів, а 3 особливо провинених данина може досягати $30-40 \%$ ); кошти від доходів фінансово-комерційних структур, утворених або взятих під контроль «воровськими» кланами.

Констатуємо, що в дослідженнях проблеми професійної злочинності чітко просліджується думка про взаємопроникнення та взаємодетермінацію професійної із іншими видами злочинності - організованою, рецидивною. Підстав для цього достатньо, адже зміна суспільно-економічних умов суспільства призводить до того, що професійні злочинці вже не такими собі «одинаками - кримінальними романтиками», і все більше переходять у сферу кримінального бізнесу: вчиняють злочини на замовлення та за наведенням, користуються допомогою і прикриттям злочинних угрупувань і корумпованих представників силових структур, врешті-решт контролюються і караються ними ж - за непокору чи порушення злодійського «кодексу честі». Звісно, не обов'язково кожен практичний прояв кримінального професіоналізму матиме всі ознаки злочинної організації. Тому вважаємо, що явище професійної злочинності слід розглядати через призму сучасного кримінологічного поняття 
«корпоративна злочинність», яке вдало інтегрує і пояснює вище перелічені характеристики цього сталого явища. Професійну злочинність вважаємо структурним елементом явища корпоративної злочинності, перспективним для практичного оволодіння і запобігання йому на основі теоретичного осмислення явища (феномену) злочинного корпоративізму.

\section{Список літератури:}

1. Ферри Энрико. Преступные типы в искусстве и литературе / Энрико Ферри. - Спб. : типогр. В. Я. Мильштейна, 1908. - 173 с.

2. Тард Габриэль. Преступник и преступление. Сравнительная преступность. Преступления толпы / Габриэль Тард ; сост. и предисл. В. С. Овчинского. - М. : ИНФРА-М, 2014. - $391 \mathrm{c}$.

3. Гуров А. И. Профессиональная преступность. Прошлое и современность / А. И. Гуров. - М. : Юрид.лит., 1990. - 304 с.

4. Шеслер A. B. Криминологическая характеристика и профилактика профессиональной преступности : учеб. пособие / А. В. Шеслер. - Тюмень : Тюменский юрид. ин-т МВД РФ, 2004. - 61 с.

5. Зелинский А. Ф. Криминальная психология / А. Ф. Зелинский. - К. : Юринком Интер, 1999. - 240 с.

6. Даньшин И. Н. Общетеоретические проблемы криминологии : монография / И. Н. Даньшин. - Х. : Прапор, 2005. - 224 с.

7. Хохряков Г. Ф. Криминология : учеб. / Г. Ф. Хохряков ; отв. ред. В. Н. Кудрявцев. М. : Юристь, 1999. - 511 с.

Пивоваров В.В. Профессиональная преступность как проявление преступного корпоративизма.

В статье рассматривается явление профессиональной преступности как проявление копроративной преступности.

Ключевые слова: корпоративная преступность, профессиональная преступность, организованная преступность.

Pyvovarov V. V. Professional crime as a manifestation of a criminal corporatism.

The article deals with the phenomenon of professional crime as a manifestation corporate crime.

Key words: corporate crime, professional crime and organized crime. 


\section{Розширена анотація}

статті Пивоварова В. В. на тему :«Професійна злочинність як прояв злочинного корпоративізму»

Pyvovarov V. V., Candidate of Law, associated professor of Department of criminology and legal and executive law, Yaroslav Mudry National Law University, Kharkiv

An extended abstract of a paper on the subject of:

\section{PROFESSIONAL CRIME AS A MANIFESTATION OF A CRIMINAL CORPORATISM}

Problem setting. In the writings of scholars of professional crime problem, its nature, the nature of the content viewed from different perspectives. Realy, it is proposed to consider it a separate type of crimes, or part of recidivism or organized crime, or even a kind of crime of political elites. Thus the phenomenon of professional criminologists crime needs attention and a thorough investigation. Question describe professional criminal behavior such persons in criminology was quite problematic.

Recent researches and publications analysis. Challenges professional crime investigation at different times and in different aspects such engaged in foreign and domestic scientists as Enrico Ferri, Gabriel de Tarde, A.I. Gurov, O.V. Shesler, A.F. Zelinsky, I.M. Danshin, G.F. Hohriakova and other scientists - criminologists, criminologists, sociologists, psychologists, psychiatrists and others. The writings of scholars of professional crime problem, its nature, the nature of the content viewed from different perspectives. Yes, it is proposed to consider it a separate species (kind of) crimes or part of recidivism or organized crime, or even a kind of crime of political elites. Thus the phenomenon of professional criminologists crime needs attention and a thorough investigation. 
Paper objective. The concept of a professional criminal, professional crime is often interpreted arbitrarily. Meanwhile, the problem of stable, long-term, skilful criminal behavior has ancient historical roots.

Paper main body. It should be noted that indeed a professional criminal activity is permanent and sustainable. Professional criminals for a long time repeatedly commit crimes that initially provides them a habit that then turns back to normal behavior. Therefore, you should agree with the scientists who examined the criminal professionalism as a kind of conscious thought-out in every detail previously prepared social parasitism.

Of particular importance for improving the criminal qualification has communication and interaction, during which the transfer takes place and criminal experience. Where necessary, organized workshops, such as the manufacture of master keys, firearms, knives, shows silent penetration of a particular object, physical training, learning unarmed combat, possession of knives, card and other methods.

Conclusions of the research. The reason for this is enough, because the changing socio-economic conditions of society leads to the fact that professional criminals are loners, and more are moving into the sphere of criminal business: committing crimes by ordering and guided, assisted and cover criminal gangs and corrupt representatives of power structures, controlled and punished them. Not necessarily every practical manifestation of criminal professionalism have all the hallmarks of a criminal organization. Therefore, we believe that the phenomenon of professional crime should be viewed through the prism of contemporary criminological notion of "corporate crime", which successfully integrates sustainable above listed this phenomenon. Professional crime believe structural element of corporate crime, promising practical understanding and learning, and most importantly - a theoretical understanding of the phenomenon of criminal corporatism.

Key words: corporate crime, professional crime and organized crime. 